\title{
The Development of
}

\section{a Program for the}

Genetic Improvement of Douglas-fir in British Columbia

\author{
By A. L. ORR-EWING \\ " $\because$ the species is adaptable to radically different methods \\ of breeding."
}

\begin{abstract}
The Douglas-fir, one of the most important species in western North America, has been widely planted in coastal British Columbia since 1930. The present measures being taken by the British Columbia Forest Service, Industry and the University of British Columbia to improve the genetic quality of the large amounts of seed required, are discussed. These include seed production areas, selections of plus trees in clone bantss and seed orchards, together with the research programs being undertaken by all three organizations. It is noted that at the present time more than go per cent of the Douglas-fir seed is collected from unimproved stands. It is considered that the acreage of the seed production areas and the planned expansion of seed orchards will not be sufficient to ensure that future collections will be from improved seed sources. An immediate expansion of seed production areas is suggested as an interim measure. It is considered that there is great potential for the genetic improvement of Douglas-fir as it has already been demonstrated that the species is adaptable to radically different methods of breeding.
\end{abstract}

\section{Résumé}

Le développement d'un programme pour l'amélioration génétique du sapin de Douglas en Colombie-Britannique.

Le Sapin de Douglas, une des essences principales de la côte ouest de l'Amérique du Nord fut planté avec profusion, depuis 1930, dans la région côtière de la Colombie Britannique. L'auteur rapporte les mesures prises à l'heure actuelle pour
Research Division,

B.C. Forest Service

Victorio, B.C.

ODC 165.3:(711)

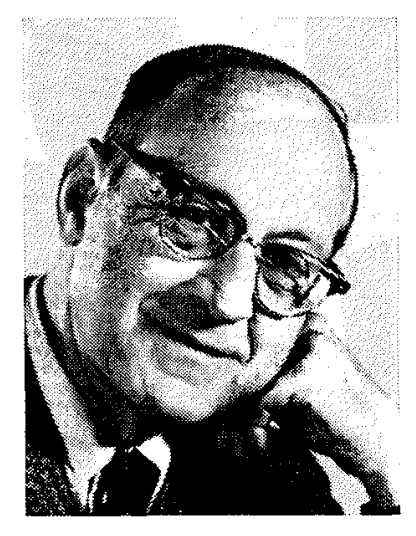

l'amélioration de la qualité des graines (pour une quantité énorme, faut-il dire) par le Service Forestier de la Colombie Britannique, l'Industrie et l'Université de la même province. Ces mesures s'appliquent aux: peuplements porte-graines, à la sélection d'arbres "plus", à la création de banques de clones et de verger's à graine; elles touchent même tous les programmes de recherches entrepris par ces trois organismes.

A l'heure actuelle, disons que plus de $90 \%$ des graines de Douglas utilisées proviennent de peuplements naturels. On prétend également que les surfaces des peuplements réservés pour la production de graines ne pourront suffire à assurer que toutes les collections de graines viendront dans l'avenir de peuplements améliorés.

On recommande donc, pour l'immédiat, à titre de mesure temporaire, d'accroitre la superficie des aires de production de semences. La possibilité d'amélioration du Douglas est réelle à cause du grand potentiel génétique de cette essence; on a déià démontré tout récemment d'ailleurs, comment cette essence pouvait s'adapter à des méthodes de cultures révolutionnaires.

\section{Introduction}

It is generally recognized that the genus Pseudotsuga contains six species, four of which occur in western China, Formosa and Japan. The remainder are in western North America, the one, Pseudotsuga macrocarpa (Vasey) Mayr having a limited range in southern California and possibly Mexico. The other, Pseudotsuga menziesii (Mirb) Franco, the Douglas-fir, is one of the most important forest species in North America. Its distribu- 
tion is so wide that it has not yet been precisely defined but it is known to extend some 3000 miles from latitude $19^{\circ}$ in southern Mexico to latitude $55^{\circ}$ in northern British Columbia. It extends another 1000 miles from the west coast to the east. The Douglas-fir grows under a wide range of environments varying in elevation from sea level to 9500 feet and in climate from the rain forests in western Washington to extremely arid conditions in New Mexico. Two varieties of this species are commonly recognized, namely P. menziesii (Mirb.) Franco var. menziesii, the coastal Douglas-fir and P. menziesii var. glauca (Beissn.) Franco, the Rocky Mountain Douglas-fir (Fowells 1965). There is some introgression between the two but the coastal variety is much the more valuable.

The Douglas-fir is an extremely important species in British Columbia and has been widely used in reforestation from the time the first plantations were established on the coast in 1930. From 1930 to $1968,547,515$ acres had been planted in the province (B.C. Forest Service Annual Report, 1968). Some 502,902 acres of this total has been planted on the coast and it is estimated that 95 per cent of this acreage is reforested with Douglas-fir. The importance of this species for future reforestation is also evident. In 1969, sufficient seed was sown in the B.C. Forest Service nurseries to produce $54,632,000$ two-year-old seedlings for planting in 1971 , by both the B.C. Forest Service and Industry. Nearly 60 per cent of these seedlings will be Douglas-fir and 51 per cent of these will be planted on the coast. When it is considered that two viable seeds have to be sown in the nurseries to produce one two-year-old seedling, it is evident that considerable quantities of Douglas-fir seed are required. It is, therefore, pertinent to discuss what measures are being taken and will be taken in the future to ensure that sufficient quantities of the seed collected are of improved genetic quality. These measures are necessarily divided into those already on a production scale and those still in the research stage.

\section{A. Production Programs}

\section{Seed Production Areas}

Seed production areas are usually young but sexually mature stands located in the areas from which seed is required. They are the first step in genetic improvement as all trees with crooked stems and slow growth are removed leaving only the best trees for cone collection. As Squillace (1969) has pointed out, the establishment of such areas is a relatively cheap method of obtaining seed of known origin almost immediately with the possibility of a modest genetic improvement. According to Rasmussen (1969) there are now 19 B.C. Forest Service and Industrial seed production areas on the coast totalling 62 acres. All production to date, however, has come from 11 of these areas, 47.7 acres in all. The first seeds were sown in 1960 and $3,780,000$ seedlings have since been planted on the coast. A further $4,840,000$ seedlings are still in the nurseries.

The influence of seed production areas on improving the genetic quality of Douglas-fir seed however, has been small. In the Vancouver Forest District there are now $14,562.1$ pounds of seed of this species in storage, but only 6.1 per cent of this total came from seed production areas, the remainder was all collected by the B.C. Forest Service and Industry from unimproved stands. This Forest District contains twelve million acres of forest land on Vancouver Island and the mainland (Forest Inventory Statistics of British Columbia 1969).

\section{Selection of Plus Trees and Establishment of Seed Orchards}

Squillace (1969) has pointed out that the phenotypic selection of superior individuals is a basic part of most present forest tree improvement programs. Through mass propagation of the selections, the breeder hopes to make a genetic gain. In 1957, the first selections of superior individuals, commonly referred to as plus trees, were made by the B.C. Forest Service in natural stands of Douglas-fir. The Tree Improvement Board was established in 1959 and largely through the efforts of the first chairman, W. G. Burch, the laborious task of selecting plus trees was accelerated with industrial cooperation. Some 445 trees have now been selected over a wide range of elevations throughout Vancouver Island and the Lower Mainland. The main cooperators have been the B.C. Forest Service, Industry and the Faculty of Forestry, University of British Columbia, the latter making some early selections in 1959 (Walters et al, 1960). The criteria for selection has already been adequately described by Heaman (1967). This selection program was the first positive step taken to ensure that there would be adequate material from natural stands for both seed orchards and breeding. The initiation of the program, moreover, was most timely as some of the stands cruised have since been logged and at least 52 of the selected trees have already been either felled or destroyed by fire. Fortunately all had been propagated previously. Scions have been removed by all cooperators from the selected trees and grafted into the B.C. Forest Service, Industrial and University clone banks which now total 108 acres (Rasmussen 1968).

Some 115 of the selected trees have already been used in the establishment of the ten Indus trial and one B.C. Forest Service seed orchards, a total of 73 acres. Very little seed, however, has been produced to date as unexpected problems have been encountered. The most serious has been the delayed incompatibility of rootstock and scion resulting in the latter growing more rapidly and causing "overgrowth". This phenomenon which is widespread in both clone banks and seed orchards has caused considerable mortality. At present, no permanent remedy 
has been found once it has developed. "Overgrowth" has caused considerable extra expense and has certainly delayed seed production. In several instances, clonal seed orchards already established are now being converted to seedling seed orchards. Attempts to circumvent the problem by propagating the clones from cuttings are being made by Brix et al. (1969). The erratic production of cones from some clones is also a matter of concern. It has been found that not only are some clones producing few, if any, cones nine years from grafting but that there is great variation in production between the ramets of a single clone (Orr-Ewing, 1969).

\section{B. Research Programs}

\section{Industry}

The first pollinations were made in 1966, some 86 crosses between plus trees being made by two Companies on their clone banks. The 2,096 seedlings produced have since been planted. In 1968, 244 crosses were made by four Companies and 21,034 filled seeds were obtained. The major part of this was sown in 1969 and most of the seedlings will be used for a cooperative progeny test. This will be directed by Dr. O. Sziklai, Faculty of Forestry, University of British Columbia, who is technical adviser to the Companies represented in the Tree Improvement Board.

\section{Faculty of Forestry, University of B.C.}

The present program is concerned with many aspects of forest genetics dealing with both Douglas-fir and other species (Sziklai, 1969). Only those dealing directly with the breeding of Douglas-fir, however, can be discussed. The first successful pollinations of Douglas-fir with water suspension of pollen were made by Allen et al. (1962). This method can be used in conjunction with aerial or ground spraying for both seed production areas and seed orchards. A detailed study has been made to describe the variability, to evaluate the combining ability and to calculate the heritability values for twelve seedling characteristics of Douglas-fir (Sziklai, 1964). The combining ability of four trees was tested by a polyallel cross with all possible 16 combinations. It was found that intra-specific crosses could yield significantly different results in 132 day old progenies grown in a growth chamber. The progenies were later planted and it was found that at five years the progeny from one tree in all combinations consistently surpassed in height the remaining progenies. This endorsed the earlier results obtained in the growth chamber (Cosco, 1968). Further crosses were made in 1966 and again in 1968 but these have not yet been fully evaluated.

\section{Research Division, B.C. Forest Service}

There are three possibilities for breeding Douglas-fir, each of which could lead to seed orchards which would be greatly superior to those established with untested clones. The first entails finding the best combinations among the plus trees selected in B.C. and then establishing seed orchards with the best of the fullsib crosses. A start has recently been made on this course by Heaman (1969)

A second possibility is intraspecific crossing, often called racial or provenance crossing, as it involves crosses between trees of the same species in widely separated populations. It should not be confused with interspecific crossing which is between trees of different species. This, however, does not have the same possibilities (Orr-Ewing, 1966). Intraspecific crossing, however, has great potential with a species as widely distributed as Douglas-fir. It is of particular interest in B.C. where the species is at the northern limit of its range and where the optimum growth occurs further south. No racial crosses with Douglas-fir had been previously reported so far the study has been largely exploratory and confined to sampling wide geographic regions. The first crosses with trees from Lake Cowichan on Vancouver Island were made in 1963 and 1964 with pollen parents from both coastal and interior B.C., Washington, Oregon and California (Orr-Ewing, 1966). The nursery results were most encouraging so further crosses were made in 1965, 1966, 1967 and 1968, the pollen parents coming from northern British Columbia, Alberta, Washington, Oregon, California, Arizona and New Mexico. The widest cross yet made involved a seven-year-old Douglas-fir at Lake Cowichan grown from seed which

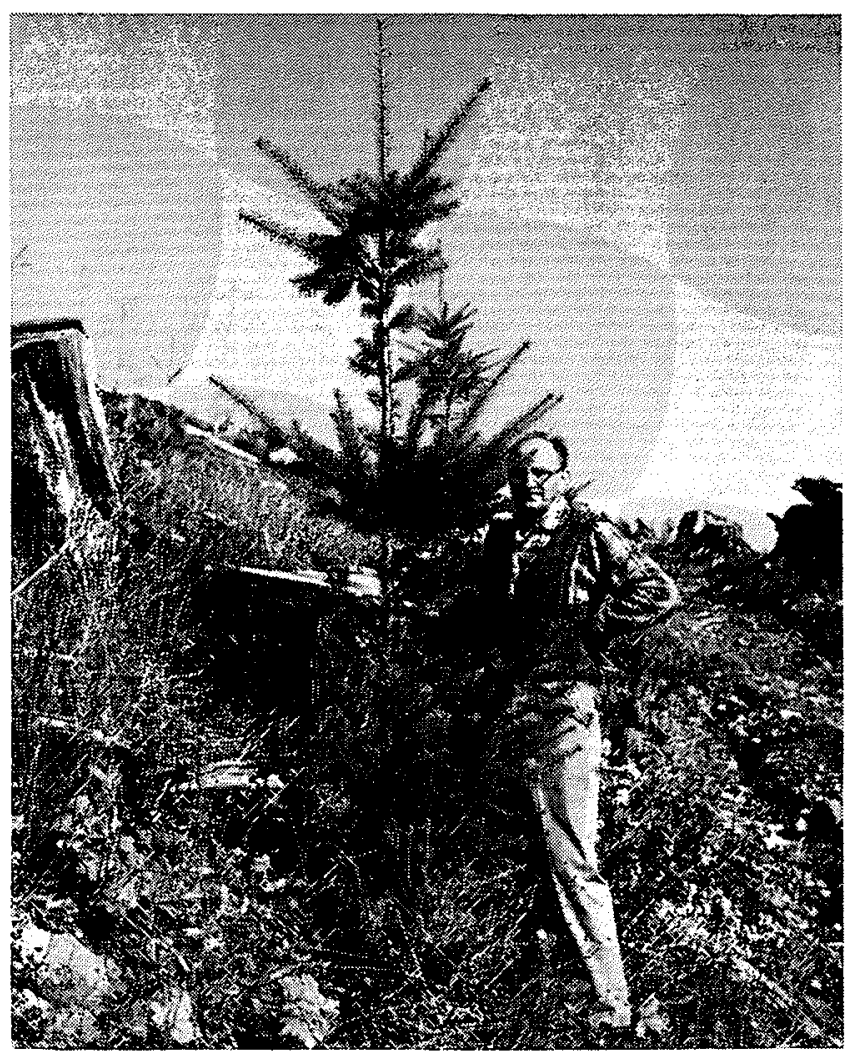

Fig. 1. - The result of a 1963 cross between a Vancouver. 1 stand seed and Oregon pollen parent. Age six years. 
had been collected in Mexico at latitude $29^{\circ} 10$, elevation 7500 feet. The pollen parent came from northern British Columbia at latitude $54^{\circ} 30$, elevation 3000 feet. The fact that viable seed can be obtained from crosses between trees separated by more than 25 degrees of latitude demonstrates the remarkable genetic stability of Douglas-fir.

Some 37,786 seedlings have already been planted on 19 test sites selected at different elevations and in different environments on Vancouver Island and the Lower Mainland. The seed parents used are also crossed with B.C. plus trees as pollen parents for controls and, in addition, their wind-pollinated seed is used whenever possible for each test site. No special care is given to the seedlings except to ensure that they are well planted as the objective is to find out whether or not they are superior to those being planted at the present time. In 1966 and 1968 only clones of the plus trees were used as seed parents. A further 43,000 seedlings from the 1967 and 1968 crosses now in the nursery will be planted on additional test sites in 1971 .

These will be maintained regularly for at least 15 years when the final assessments will be made. The early performance of some of the north-south crosses now planted for three and four years are most promising but there is need for cautious assessment at this early stage. The knowledge that the Douglas-fir will cross readily within its extensive range, however, introduces enormous possibilities for eventually establishing specific seed orchards involving wide crosses of proven combinations. In the meantime the breeding arboretum at Lake Cowichan is being rapidly developed to include both clones and seedlings collected throughout the range of Douglas-fir in Canada and the U.S.A. This will ensure that future pollen supplies will be adequate for extensive breeding and that promising crosses can be repeated.

A third possibility is inbreeding which includes the self-pollination of selected trees, the establishment of inbred lines, further selection and inbreeding with final outcrossing between lines. This method has been remarkably successful in agriculture but has received little attention from tree breeders. The main obstacles have been self-incompatibility, the difficulties of raising the first generation inbreds to sexual maturity and the suspected delay between generations. The present program is only a small one but it has already shown that these obstacles are by no means insurmountable with Douglas-fir. The yield of viable seed from selfpollination may be very low but it is also highly variable and pollinations can always be repeated. The first generation inbreds are not necessarily all weak and there has been no real problem to their establishment. Inbreeding to the second generation has proven no more difficult and it is possible to inbreed to the second generation

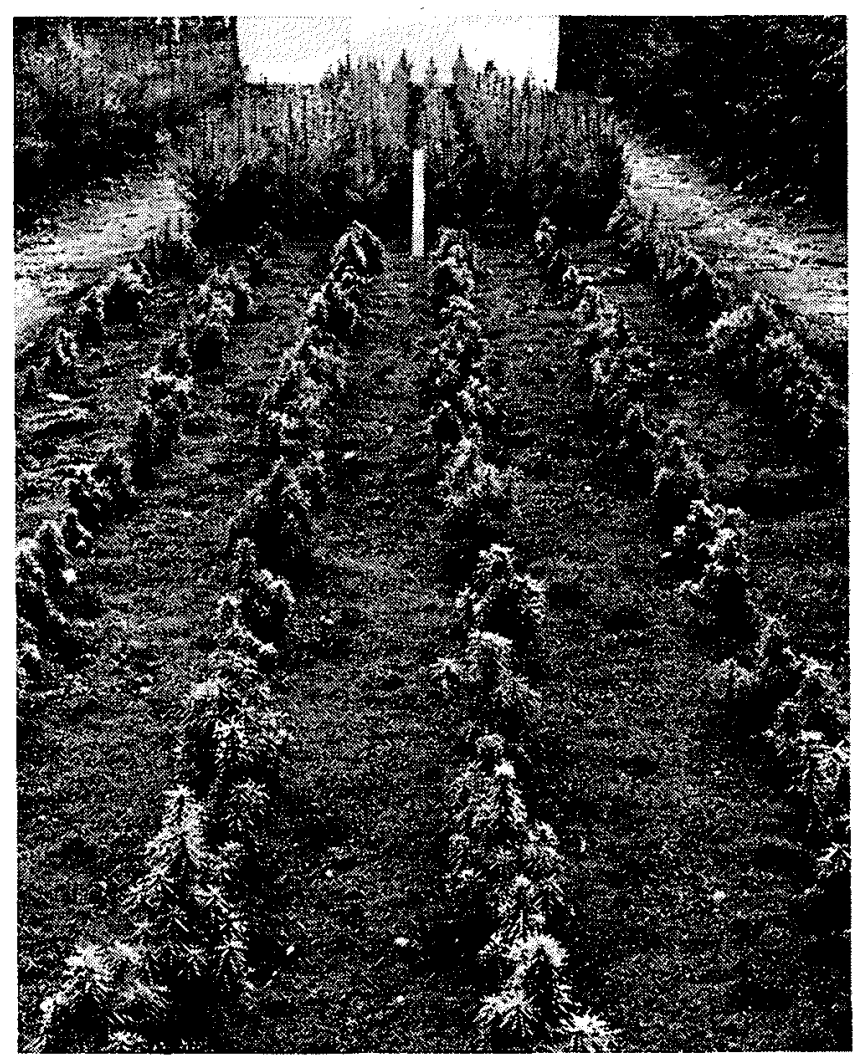

Fig. 2. - Segregation into dwarf and tall seedlings in a second generation in bred line. Age two years.

in less than ten years. Trees from different inbred lines, moreover, can be crossed (Orr-Ewing, 1965). The next stage will be to establish more inbred lines from the selected trees and to cross the second generation inbred lines. The potentialities of an inbreeding program with Douglas-fir are still largely unknown but there is no question that inbreeding is a most important method for obtaining basic information on gene action. A recent example is the striking segregation into dwarf and tall seedlings recently reported in two second generation inbred lines (Ort-Ewing, 1969).

\section{Conclusions}

Firstly, as regards the production program, a start has certainly been made towards implementing an improvement program for Douglas-fir. There are now 73 acres of clonal and seedling seed orchards on the coast with a planned expansion of a further 54 acres making a total of 127 acres. Some important questions, however, remain. How much seed will be produced and how long before even the established seed orchards are in full production? Finally, is the total acreage adequate to drastically reduce the amount of seed now being collected from natural stands? This latter question can best be answered by reviewing a similar program in Finland where the forest area is only 38.7 per cent of that in B.C. This program only began in 1947 but the Foundation of Forest Tree Breeding recently reported that in one year the area of established seed orchards for three species increased from 1112 to 3460 acres. There are already 5782 acres 
of seed orchards of Scots pine with a national goal of 8495 acres (Metsänjalostussäätiö, 1968). With the known erratic cone production of Douglas-fir, the total acreage of both the established and proposed seed orchards can hardly be considered adequate. It is, perhaps, natural that the high incidence of overgrowth, erratic cone production and increasing costs of maintenance have inevitably resulted in some scepticism concerning seed orchards and tree breeding in general. The furtherance of research programs towards overcoming some of these problems and in demonstrating just what can be achieved in the breeding of Douglas-fir is, therefore, of major importance at this time.

There are certainly sufficient selected trees for use in an expanded seed orchard program, but there is the question of time between the establishment of an orchard and production. In order to avoid too much dependence upon seed orchards at this time, the acreage of seed production areas should be greatly increased as the present area of 62 acres is insufficient. In the last nine years only $8,620,000$ seedlings have been produced, this should be compared with the 37 million seedlings from plus stands growing in the nurseries of the Foundation of Forest Tree Breeding in 1968 (Metsänjalostussäätiö 1968). Seed production areas are a sound investment as not only is cone collecting greatly simplified and more accurately defined, but there is some genetic gain. The importance of selecting only the best phenotypes for cone collections in young stands of Douglas-fir has already been demonstrated in a study initiated in 1954 (Orr-Ewing, 1967). It was shown that poor form was strongly inherited and that even a crude form of selection involving neither propagation nor breeding resulted in some improvement in the growth and form of the progenies. A further point regarding seed production areas is that seed collections from natural stands will become increasingly difficult as the natural forest is removed and replaced with plantations not necessarily from the same seed source. In some locations where no young stands are available, the establishment of a seed production area from local seed may be necessary. Research on the difficult problem of initiating cones and pollen in young Douglas-fir stands reported by Ebell (1966) should be intensified and concentrated on such areas.

Secondly, as regards the research programs it is evident that the Douglas-fir is an admirable species for breeding. Its wide distribution, variability and response to such diverse methods of breeding as racial crossing and inbreeding are in many ways unique. The potential in an improvement program for this species can best be realized from the halfsib progeny test initiated more than 50 years ago by the U.S. Forest Service (Munger et al. 1936). Silen (1966) who is analyzing the results found that within a race the best families from wind-pollinated parents outproduced the poorest families in timber volume per acre at 50 years by ratios of $2: 1$ and sometimes over 3:1. It should be appreciated that this study was started years before there were any selection or breeding programs.

\section{Acknowledgments}

Assistance in providing information for this paper was given by Dr. O. Sziklai, University of British Columbia and Messrs. A. Bamford, B. Devitt and C. Heaman of the B.C. Forest Service.

\section{Literature Cited}

ALLEN, G. S. and O. SZIKLAI, 1962. Pollination of Douglasfir with water suspensions of pollen. For. Sci. 8, 64-65.

British Columbia Forest Service Annual Report 1968, Victoria, $103 \mathrm{p}$.

BRIX, $H$. and $H$. BARKER, 1969. Rooting of Douglas-fir and western Hemlock cuttings, Bi-monthly Research Notes 25 , p. 22.

cosco, J. N. 1968. Analysis of the reciprocally crossed progeny of Douglas-fir parents A, B, E, 11. B.Sc. thesis, Fac. of For., Univ. of B.C. 70 p.

EBELL, L. F., 1967. Physiology of flowering and cone production in Douglas-fir. Proc. 10th Meeting Committee on For. Tree Breeding in Canada. Part 2 1966, 33-34.

Forest Inventory Statistics of British Columbia, 1969. Forest Inventory Division, B.C. Forest Service, Victoria, $194 \mathrm{pp}$.

FOWELLS, H. A. 1965. Silvics of forest trees of the United States. U.S. Dept. Agric. For. Serv. Agric. Handbk. 271, 762 p.

HEAMAN, J. C. 1967. A review of the plus tree selection programme for Douglas-fir in coastal British Columbia. B.C. For. Serv. Res. Note 44,27 p.

HEAMAN, P. C. 1969. Controlled crossing and second generation selection of Douglas-fir plus trees. For. Res. Rev., B.C. Forest Service. In Press.

METSÄNJALOSTUSSÄÄTIO 1968. The activity of the Foundation for Forest Tree Breeding in Finland in 1968, Helsinki, $31 \mathrm{p}$.

MUNGER, T. T., and W. G. MORRIS, 1936. Growth of Douglas-fir trees of known seed source, U.S. Dept. Agric. Tech. Bull. 537, $40 \mathrm{p}$.

ORR-EWING, A. L. 1965. Inbreeding and single crossing in Douglas-fir. For. Sci. 11, 279-290.
1966. Inter- and Intraspecific crossing in Douglas-fir, Pseudotsuga menziesii (Mirb.) Franco. Silvae Genetica 15, 121-126.

ORR-EWING, A. L. 1967. A progeny test of Douglas-fir to demonstrate the importance of selection in forest practice. B.C. For. Serv. Res. Note 43, 29 p

1969. A clone bank of Douglas-fir. B.C. For. Serv. Res. Note 45, $13 \mathrm{p}$.

1969. Inbreeding to the $S_{2}$ generation in Douglas-fir. Second World Consult. For. Tree Breeding, Washington D.C., 13 p.

RASMUSSEN, S. 1969. B.C. has 11 seed orchards, 19 seed producing areas, the T.I. Board reports. Forest Industries, 5.40 .

SILEN, R. 1966. A simple progressive tree improvement program for Douglas-fir, U.S. Forest Serv., Pac. N.W. Forest Range Exp. Sta. Res. Note $45,13 \mathrm{p}$.

SQUILLACE, A. E. 1969. Development and action programs for forest tree improvement. Second World Consult. Forest Tree Breeding, Washington, D.C., $15 \mathrm{p}$.

SZIKLAI, O. 1964. Variation and inheritance of some physiological and morphological traits in Pseudotsuga menziesii (Mirb.) Franco var. menziesii. Ph.D. thesis, Fac. of For., Univ. of B.C., 136 p.

1969. Forest genetics and tree breed ing at the Faculty of Forestry. University of British Columbia. Proc. 11th Meeting Committee on For. Tree Breeding in Canada, Part 2. 1968, 157-163.

WALTERS, J., J. SOOS, and P. G. HADDOCK 1960. The selection of plus trees on the University of British Columbia Research Forest, Haney, B.C. Univ. of B.C., Fac. of For., Res. Pap. No. 33, 11 p. 